Ghosting in the outback Noir

\author{
Greg Dolgopolov \\ University of New South Wales \\ gregd@unsw.edu.au
}

\begin{abstract}
Copyright(C 2021 Greg Dolgopolov. This text may be archived and redistributed both in electronic form and in hard copy, provided that the author and journal are properly cited and no fee is charged, in accordance with our Creative Commons Licence.
\end{abstract}

\begin{abstract}
Who was the 'jolly swagman' in Waltzing Matilda, Australia's unofficial national anthem? In this essay I argue that the ghost of the swagman can be heard in a number of recent de-colonising crime narratives. Outback Noir is a relatively recent genre category that describes a new wave of Australian crime films that highlight Indigenous and white relations and take a revisionist approach to traditional history. These films often feature redemption stories that highlight effective collaborations between Indigenous and white policing practices. Uncovering a rural communities' dark, repressed secrets in order to solve a current problem is a common trend in Outback Noir cinema. I examine Patrick Hughes' 2010 film Red Hill as an early provocative example of Outback Noir and as modern reimaging of the Waltzing Matilda narrative with the swagman's avenging ghost exposing the social fractures and corruption that are destroying rural communities. I argue that the Outback Noir genre with its focus on revenge-redemption narratives shapes the cultural dialogue around putting the ghosts of the colonial past to rest.
\end{abstract}

Key Words: Outback Noir; Neo-Westerns; Waltzing Matilda; Red Hill; Mystery Road; Goldstone 
"I could never decide if the scrub actually was evil or if it was just the stories shivering in my young mind. But I also remember how everything was real the ghosts truly were there at the same time as they were just steam."

\section{Ross Gibson, Seven Versions of an Australian Badland (2002: 21)}

Outback Noir, as a uniquely Australian crime genre, has a weirdly melancholic approach to the past, ghosts and guilt associated with 'frontier justice'. The ghost of the jolly swagman pervades the genre. Uncovering a rural communities' dark, repressed secrets in order to solve a current problem is a common trend in Outback Noir cinema. In describing the collection of paintings and photographs at the Ian Potter Museum of Art subtitled "The Australian Gothic", curator Suzette Wearne advocated that, "Our collective repressed is haunted by the ghosts of our indigenous past. She suggests "a fear of retribution for the mistreatment of Aboriginal people explains the menace projected onto the landscape in the Australian gothic. Where the Aboriginal presence is denied, or repressed, the landscape is embedded with this trauma - the ghosts of the brutal colonial encounter" (Power 2015). The notion of the ghost may suggest something that is not quite there anymore, but that lingers as an invisible sacred force or settler guilt that plays out as tragedy in the present - visceral and corporeal. Think the jolly swagman - ever present in song and a haunting ghost in our imagination. 'Waltzing Matilda', Australia's unofficial national anthem may provide some insights into Australian cinema's recent trend in representing crime. This dirge that both uplifts the nation's spirits at international sporting events and reminds us of our mythical national commitment to commit suicide rather than succumb to the rough justice of the police is dripping in noir sensibilities of moral conflict, ghosting, perversions of history and the uncanny. In this essay I seek to examine the ghostly hauntings of the itinerant, not always jolly swagman figure in recent Outback Noir cinema with the inversion of the traditional bucolic image of the Australian outback into something dark and sinister, but also potentially redemptive. As Avery Gordon asserts, "when the over-anddone-with comes alive, when what's been in your blind spot comes into view. Haunting raises spectres, and it alters the experience of being in time, the way that we separate the past, the present and the future" (1997: xvi). The jolly swagman may have been in our blind spot all this time and with him a whole host of Indigenous characters who have been shunned, imprisoned, destroyed or kept silent. With the recent wave of Outback Noir films, they are returning often with a vengeance.

'Waltzing Matilda' is without doubt one of the most passionately contested Australian texts. Whether it is the meaning or symbolism of the song, or the identity of the characters or the perennial debates about it being more than our 'unofficial' national anthem - Waltzing Matilda continues to manifest considerable passion and debate. What appears to be less contentious is the incongruous 'weird melancholy' that Marcus Clarke observed of the Australian landscape of the 1800s. Perhaps it is the same weird melancholy that the song provokes as a commemorative epithet that has been used as a rallying folk song espousing a national identity that is a celebration of paradoxes and sleights-of-hand in honouring and repressing history. Writing in the music section of The Guardian, Patrick Marlborough, claimed that 'Waltzing Matilda' was Australia's creepiest ballad and he provided personal recollections that perceived 
reviving the past as somehow uncanny to support his assertion. "I put it to you that Banjo Paterson's banger and monster-mash, about an outlaw swagman gone troppo, epitomises the madness that haunts the Australian psyche", Marlborough claimed. This article did precipitate some interesting reader comments, 240 to be exact on The Guardian site. One comment, in particular, stood out:

The song seems to make more sense if the swagman is thought of as an aboriginal type swagman trying to make it in a white man's world. The swagman doesn't make sense as an icon of some Australian Digger type trying to eek out a living during a depression; or as some shearer type wandering around from farm to farm peddling his skills during tough times; or as some Ned Kelly like honorable outsider outlaw type character; or as some rebellious remnant of the Eureka Stockade. None of the traditional icons make sense. However, it does seem to make more sense today as an icon of aboriginal racial alienation, although it may be contrary to Banjo's original meaning, whatever it was. (mancan18)

This was not the only comment to have made a clear link between the song, the bush setting and Aboriginal people who were the victims of multiple miscarriages of justice. Neither the article nor the comment is about cinema, but they do raise important questions for Australian film studies of the connection between 'Waltzing Matilda', Indigenous themes, and the connection to Outback Noir, crime and ghosts. What if the mythical character of the swagman is the story of an Indigenous man's attempt to evade colonial injustice and that this moment of original crime has been hiding in plain sight for more than a century concealed by debates of whether the identity of the swagman was the murdered shearer "Frenchy" Hoffmeister or if it was a symbolic of our struggle to find our own identity. Professor Ross Fitzgerald suggests “there seems to me no doubt that Waltzing Matilda wasn't just a little romantic ditty, it was very deep, multi-faceted political allegory and lament" (2010). Waltzing Matilda is not a cold case but a search for a shifting identity.

Let us then imagine, in a politically allegorical way, that the swagman was an Indigenous man. What could be the impacts on Australian crime narratives and representations of Aborigines as summarily criminalised without experiencing justice - choosing to commit suicide rather than succumb to the authorities? 'Waltzing Matilda' has enjoyed many different musical interpretations as well as more than a dozen cinematic iterations with both in Australia and abroad. The majority of these 'uses' highlight a shorthand of national identity genuinely (Australia 2008) or satirically (Three Summer, 2017) or in a complex melancholy, end-of-theworld way (On the Beach, 1959). Not surprisingly, the song's more explicit themes addressed in the lyrics of anti-authoritarianism, ghosting, homelessness, crime and an absence of justice have not been directly addressed in cinema. However, the Outback Noir film cycle goes some way to examining this foundational story of original sin in colonial crime and the scratching back of the concealed histories of this weird melancholy. One of the earliest films of the emerging Outback Noir cycle, Red Hill (2010), written and directed by Patrick Hughes, is a symbolic inversion and rehabilitation of the swagman story but made for a present-day audience seeking moral de-colonialising redemption with their crime thriller fix. In this essay I argue that Red Hill could be read as an interpretation of the Waltzing Matilda narrative - the (imaginary) revenge by the swagman's anti-authoritarian ghost fighting entrenched privilege 
and police corruption as a celebrated social bandit. It is a revenge- redemption Outback Noir narrative that resurrects and empowers the ghosts to achieve some sort of revitalisation of the landscape.

\section{Outback Noir}

The location that unites so many Outback Noir films is the same region where Banjo Patterson penned Waltzing Matilda and where it was first performed - the Winton Shire region of Central Queensland. It is the same outback landscape that Patterson explored in 1894 that was still resonant with the recent union strikes that attracted a savage police response and only a few years earlier the brutal genocidal massacres of Aborigines at Skull Hole among other locations - all in plain sight. This unquantifiable resonance could go some way to explaining the postcolonial production of revisionist westerns and outback crime stories in this region and the inevitable turn to a noir sensibility to shine a light on what is hiding in plain sight. Some of the most prominent examples of Outback Noir that includes John Hillcoat's The Proposition (2005), Gone (2006), Ivan Sen's Mystery Road (2013) and Goldstone (2016) were all filmed in and around Winton - a difficult and challenging production location due to its isolation but offering incredible vistas and remarkable local support. These films are variations on the revisionist western, the neo-noir, the sunburnt crime narratives that in a flurry of bullets on corrugated iron reframe and contemporise colonial violence and reveal the ongoing police brutality against Indigenous people in conjunction with reverberations of ancestral trauma. Location is important for Outback Noir. It is not simply an adaptation of the highly marketable Nordic Noir into an Australian landscape. It is about provoking that landscape as a character that facilitates the criminal anthropology of digging up the past to help address a contemporary tragedy through the landscape. The concept of 'outback noir' is effective as marketing for its appeal to a national specificity based on its incongruity and inversion of the traditional noir visual iconography of the nocturnal urban scene and the presentation of the Australian rural landscape that is breathtaking and sublime. But underneath the stunning, iconic Australian imagery is a dangerous, twisted noirish world hiding in the blind spot. In examining Ivan Sen's Mystery Road, film critic Eddie Cockrell compared it to Roman Polanski's 1974 drama Chinatown, "both are sun-drenched films noirs, both feature commanding protagonists who spend much of the film doing wrong things for the right reasons, and both feature climactic showdowns in places laden with metaphor" (2013). The place of metaphor for Outback Noir is that idyllic billabong - initially peaceful and fecund but turned into a hushed-up murder scene by the arrival of the police. The unifying aspect of Outback Noir films is that they examine the trauma of the Australian frontier - the past in the case of The Proposition and Wake in Fright (Kotcheff, 1971), the future in The Rover (Michôd, 2014), but mainly the present that is skewed out-of-time in films such as The Dry (Connolly, 2020), the TV series Mystery Road (2018 - 2021), Locusts (Davis, 2019), Wake in Fright (Stenders, 2017) and Kill Me Three Times (Stenders, 2014). More recently the resurrection of the Australian gothic, mixed with the popularity of Nordic Noir and literary crime thrillers (Scrublands, The Dry, The Hunted) have coalesced to form a loose collective of films, TV series and books that examine 
our fear of the other and the dreaded revelation of repressed histories. These themes that are often set in burnt out rural Badlands tend to prosper during periods of social anxiety. Outback Noir is not just a location, but an aesthetic trope and a marketing term that blends the crime thriller that happens to be set in the outback, with a national inflection of noir iconography and post-colonial soul searching. Outback Noir is not a genre, but more of a sensibility that has become the most prevalent style for representing prestige, high concept crime in recent Australian cinema. These films continue the Australian landscape cinematic tradition, but with an accent on the western and rural crime story, while foregrounding a post-Colonial investigation into buried histories and contemporary corruption.

An important strand of Outback Noir films is focused on Indigenous investigations of a crime that is invariably rooted in the past and covered in ghostly hauntings of colonial violence that set the template for many other cinematic crime films that investigate corruption hiding in broad daylight. The characters are haunted by the past. Revenge is often the driver to resurrecting and engaging with the past in order to solve a current tragedy. The revenge theme drives some of the films into horror territory following in the steps of Wolf Creek (2005). The Marshes (Scott, 2017) and Two Heads Creek (2020) de-emphasising the investigation of a crime while playing with jump-scares, gruesome body torture and pitch-black humour. The Marshes is not a crime film, although the narrative concerns an investigation of a sort by scientists researching a complex marsh ecosystem. It twists the Waltzing Matilda story into a slasher, eco-horror film where the monster is a giant masked swagman who rises out of the billabong and gruesomely dismembers anyone who goes there. Before the monster appears, university biologist Ben (Matthew Cooper) tells his colleagues a fireside tale intended to terrify them:

“the real Waltzing Matilda happened not far from here ... it's a bit suspect don't you think? Who has ever killed themselves over a sheep... the malignant ghost of the swagman has haunted remote waterways, whistling his mournful song, and tuckerbagging anyone unlucky enough to stumble into his watery domain ... Don't say that I didn't warn you..."

The Marshes is not an adaptation of 'Waltzing Matilda', but the monster certainly provides an imaginative resurrection and inversion of Patterson's story with the swagman no longer the victim of colonial violence, but now a modern, brutal eco-warrior defending the mysteries of the land from any scientific research. In contrast, films such as Locusts, The Dry, Swerve (Lahiff, 2011) and Kiss or Kill (Bennett, 1997) highlight the recognisable noir tropes and character types, but without the same emphasis of colonial hauntings although there is the inevitable digging up of the past to solve current issues. Unlike the sleek urban streets, fluoro lights and long dark shadows of traditional noir with its chiaroscuro lighting and brooding psychologically damaged characters, Outback Noir highlight incongruities - the blinding sunlight of the outback appears to offer no place to hide or to conceal that past. But the constantly glaring sun eventually exposes the shady deals and the sun bleaches the decrepit, decaying history of corruption. Outback Noir uncovers the picture postcard outback landscapes to reveal the heat, hatred, suspicion of a zone where the past is unsettled and volatile and there is no place for future dreams. 
As the leading commentators of film noir, Silver and Ursini suggest, the noir protagonists are "often escaping some past burden, sometimes a traumatic incident from their past.... Occasionally, they are simply fleeing their own demons created by ambiguous events buried in the past... The past to a noir protagonist is no fleeting phantom. It is real and tangible and menacing. In the noir world both past and present are inextricably bound.... One cannot escape one's past, no matter how much he or she might try. And only in confronting it may the noir protagonist hope for some kind of redemption, even if it is at the end of a gun..." (2004: 15). In an inversion of traditional archetypes where the noir protagonists seek to escape the light, the Outback Noir characters are fully, blindingly exposed by the dazzling light. The brightness of the light and its intensity sear the eyeballs and dull the mind making the outback a perfect place to hide the past and dirty dealings by having them parched and bleached by the burning incandescence. The characters of Outback Noir are constantly moving to avoid claustrophobia, blindness, stagnation and possibly getting stuck in the past. If the figure of the 'swagman' in The Marshes was dark and silent, then seeing the constantly roaming Mick Taylor of Wolf Creek notoriety is probably closer to Patterson's sardonic description of the swagman figure as "jolly" and itinerant. The figure of Jimmy Conway in Red Hill performed by Tommy Lewis, a veteran of more than half a dozen Outback Noir films, is constantly in motion and is 'jolly' only in a sarcastic sense as his outlook is pessimistic. Similarly, Detective Jay Swan (Aaron Pedersen) in Mystery Road and Goldstone appears as a surly cowboy, constantly on the move and far from jolly. He is not motivated by revenge, but he is driven to attain justice for people who have been marginalised either by the community or by dark (police) forces. Solving the crime in Outback Noir is rarely about restoring justice and order, but about a realisation that the distinction between right and wrong is uncomfortably blurred. Jimmy Conway, like the swaggie, is an outcast because he was denied the opportunity of a 'fair go'. He confronted the authorities and for that he was destroyed. There is an element of the revenger's tragedy at play in Outback Noir in that search for restorative post-Colonial justice.

In an interview with Luke Buckmaster for Crickey, director Patrick Hughes explained the complex menacing figure of, Jimmy who is not a straight cut villain and anti-hero:

He's a monster and throughout the film we humanise him. I really wanted to present him as this disfigured monster, this shadow of fucking evil that stalks into this town, much the same way as the panther in the film does. Death has just come and he's come for fuckin' payback. We treated Jimmy's performance as a sort of last supper. We put all these little sensory experiences. Just little things, like him eating a cake. It's like fuck - he's been in prison for 15 years in maximum security, he'd probably enjoy to eat that piece of cake. So taste it and enjoy it because it's going to be the last thing you eat on planet earth, know what I mean? I wanted to tell a tale of revenge and I wanted to create something quite confronting. The image of an Aboriginal man with a sawn-off shotgun is pretty confronting.

Patrick Hughes developed a complex anti-hero in the figure of Jimmy Conway - a man who was at once a menacing supreme hunter and yet kind and honourable when it mattered. $\mathrm{He}$ was very specific in his casting of Tommy E. Lewis as Jimmy Conway. Lewis is a fascinating, complex figure in Australian crime cinema and it is no surprise that he has appeared in so 
many Outback Noir films and their predecessors. His performance as Jimmy Conway is inevitably infused by the memory of his blistering portrayal of another Jimmy in The Chant of Jimmy Blacksmith (1978). He appeared as Two Bob in The Proposition (2005) as a leading gang member of an outlaw band that had no fear of the police or the law. Later in his career, he was the deceptive Aboriginal politician 'Tommy' in Goldstone that precipitated the political rorting and then its revelation. He was Mundaru, a smart and wilful renegade in The Naked Country (1985) ready to take on the entitled squatters with no sense of inferiority. Tommy E. Lewis became a symbol of resistance in a range of films about frontier justice. In so many of his roles he is more than ready to take on the white boss and assert his own law and authority. From his first role as a young Indigenous man who has been exploited and wronged and who then fights back for justice and honour - most of his performances demonstrate his proud, anti-authoritarian, 'jolly' warrior spirit.

In another interview Hughes explained that he "was drawn early on to the western [genre] because of the moral code. Everyone identifies with it. In Australia we call it "country justice." At one point do you take justice into your own hands. And if vengeance is justified, that's powerful for an audience, and the story will have emotional weight" (Macaulay 2010). For Hughes, Jimmy Conway followed a moral code and understood "country justice" but when he and his family were wronged, he adopted the mayhem of frontier justice through a not quite blind pursuit of retribution. Conway becomes a classic figure of Australian antiauthoritarianism resonating clearly with the swagman who defied the authorities and rose to fame as happy-go-lucky social bandit. As Erik Hobsbawm reminds us "the point about social bandits is that they are peasant outlaws whom the lord and state regard as criminals, but who remain within peasant society, and are considered by their people as heroes, as champions, avengers, fighters for justice, perhaps even leaders of liberation, and in any case as men to be admired, helped and supported" (1972: 13). Like the ghost of Jimmy Blacksmith, Conway is an avenging social bandit and one constructed by the diegesis as a positive agent for change and fiery redemption. In the following section I will examine the film Red Hill in greater detail with a focus on the role of justice and revenge in shaping its articulation of Outback Noir and its resonance with 'Waltzing Matilda'.

\section{Red Hill}

Red Hill (2010) as an example of Outback Noir that combines a revenge crime thriller narrative blended with a neo-Western that is set in the present day but the community on the edge of an abyss is defined and damned by past crimes. It is not an adaptation of 'Waltzing Matilda' and the tune does not appear in the soundtrack, but the film exhibits a certain ghosting resonance with the story that is driven by an Indigenous man's desire for vengeance as retribution for past trauma at the hands of the community and the police.

Red Hill is the story of the unexpected connection between two very different men one long, rainy explosive night in a dying rural town: a young white city policeman Constable Shane 
Cooper (Ryan Kwanten) who moves to the small rural community to experience the quiet country life with his young family and a dangerous escaped prisoner, Indigenous man Jimmy Conway (Lewis) who is making his way back to his home in this bucolic land to exact justice from the men who raped his wife and destroyed his life. Red Hill was described by Jeannette Catsoulis of the New York Times as "a galloping revenge tale that uses young blood to unearth old sins" (2010). On Cooper's first day on the job there is an announcement that Conway has escaped jail and is heading to town. Red Hill's head of police, Old Bill (Steve Bisley) arms all the old blokes ready for a brutal confrontation. Conway is cast as a murderous monster and Old Bill as the town's saviour - a kind of inversion of High Noon. While the setting is modern, the context is one of uncovering the town's buried histories by an outsider. We find out later that Conway is returning to Red Hill to take vengeance out on Old Bill and the police and townsfolk complicit in raping and murdering his wife and framing him with the crime. Half of his face is disfigured by massive burn scars. His damaged past is inscribed on his face. Conway is an expert hunter and adept at dispatching the hillbilly perpetrators of the historic crimes one by one with a pump action shotgun, a spear and a boomerang. He is silent, merciless and relentless. Although the inept Cooper represents the law (he is the modern, sensitive version), Conway lets him go a number of times as he understands the moral codes of the conflict and the fact that Cooper is expecting a child. These would-be combatants are brought together by the unravelling of old secrets and together they uncover the truth of the past and expose Old Bill's lies and deception. Years ago Old Bill and his posse attacked Conway because of his resistance to the destruction of an ancient sacred site. In the film's denouement, Cooper and Conway together drag the long-buried truth into the light and destroy the town's perverted old law and Old Bill as its deceptive perpetrator. They release the ghost.

The representation of the Indigenous past of Red Hill is limited, but what there is appears in multiple modes - as venerated cultural traditions with talk of sacred sites and symbolically as a source of kitschy irony. In the main street at the run-down information centre there is a 'historical display' that features a mannequin of a near naked Indigenous male hunter in a staged forest scene. The display is awkward and incongruous and as Kit Harvey notes, "the display, quite literally, puts Aboriginal culture safely behind glass, as something consigned to history, a museum piece best appreciated as a relic of the past. Its singularity claims to capture all of what it means to be Aboriginal - a "primitive", "uncivilised" existence" (2012). This tacky display plays an important symbolic role in the film. It is seen three times and each time it performs a different role and each time it is seen differently. The first time is when Cooper first comes into town and sees it as a representation in microcosm of what the townsfolk think of their Indigenous history: a quaint, kitschy remnant of the past - so obvious and so awkward that it decimates any sense of ghostly agency or haunting. The second time it is Conway who sees the 'the 'historical display' this time at night and sitting on horseback from on high. A thunderclap followed by a lightening flash reveals Conway glaring at the degraded mannequin in disgust. Is the captured in fiberglass and locked up under glass 'Aboriginal elder' meant to represent him? The threat is still there as in another lightening flash Conway spots the reflection in the safety glass of a local thug hiding on a rooftop behind him poised to shoot. But Conway is too fast, and the man tumbles down off the roof scattering another goon hiding among the rubbish bins. The third and final time that the 'display' comes into view is when Cooper comes back into town with the historical secret crimes unravelling the 'historical display' that is now 
trashed: the mannequin albeit having lost an arm, is now liberated of the broken glass. In order for Indigenous culture to be resurrected the display needs to be destroyed and trashed. Its' boomerang and spear artefacts stolen and used to assassinate the historic killers to ironically highlight Conway's 'mysterious' hunting skills. This is a strangely symbolic moment in an otherwise fast paced action genre section of the film.

A feeling of fatalism imbues this Outback Noir with Conway's Indigenous agency: a brutal but righteous response to redeeming his ancestral trauma. His relentless pursuit of his victims is matched by a narrative expectation that his vengeance will have no personal redemption; that he will not survive this night of terror but that it will be his ghost that will be heard after the reverberation of bullets terminates. Conway and Cooper's informal alliance brings about a strange, but cathartic justice to the town with the bloody destruction of all the rogue cops and purifying vengeance that puts to rest the wrongs of the past. Ben Goldsmith claims that the "story opens up the questions of frontier violence, contemporary racism and the silences of local history, as well as issues around environmental protection and the economic future of once-thriving rural towns' (2015: 220). The frontier violence is resurrected, but this time reversed. It inverts the expectations of the western with the film squarely not on the side of the cowboy coppers and weather-beaten mountain men. Patrick Hughes fashioned Indigenous vengeance as contemporary entertainment that captures the zeitgeist where viewers seek the visceral feeling of retribution, if not the rehabilitation of ancestral trauma. Restaging a frontier massacre of Aboriginal people as retributive bush justice does not necessarily transform the mythical Conway-the-ghost as it just repeats the history of brutality again and again in a desperate search for resolution. But the ghosting remains. In discussing the Australian Colonial Gothic in the literature of the $19^{\text {th }}$ century Ken Gelder observes that a story about a bush ghost "mobilises its ghost as a kind of symbolically displaced image of settler guilt, its blackness suggesting something that is not quite there anymore but which lingers on as a kind of unwanted companion. Settlers who see it die soon afterwards. At this post-frontier moment, the killing and dispossession of Aboriginal people are distanced from settler memory; the Gothic, on the other hand, breaches that distance by turning frontier encounters into a kind of special effect that reaches into a settler future (the "future empire") and negates it" (9-10). The connection of Conway with the mythical black panther that appears mysteriously in the film points to his symbolic freedom and his magical, dangerous ghost like appearance in redefining settler guilt. No one claimed that this film was subtle or that it avoided cliches and stereotypes but that makes it all the better to provoke debate.

In Ivan Sen's Outback Noir classics, Mystery Road and Goldstone, there is a similar examination of the injustices of the past, the buried ancestral trauma and the divisions between black and white Australia as issues of the ambivalence of figures of authority. In contrast to Red Hill, the Indigenous protagonist is not destroyed in the process of retribution, but there is considerable collateral damage along the way for the black and white members of the rural community. All three films feature three different white cops who are seemingly surrounded by a racist paradigm, albeit they all turn out to be decent men capable of cross-cultural collaboration in the heat of battle. In the vast expanses of the Australian outback with the sun so blinding and the landscape so parched, the light conceals far more than it reveals. It is in the bright midday sun of the godforsaken Goldstone where the Mayor (Jacki Weaver) makes unveiled threats over tea and freshly made cake. It is in the heat of the day that bribes are 
offered, murders executed, and honest cops attacked. But it is by a burning barn in the dead of night, high on the hill at Red Hill that the past is revealed and Conway the monster avenged and at the same time, historicized (through flashbacks we learn what devilry brought him there) and in the process humanised.

Film noir traditionally explores the moral trauma of combat or corruption on its protagonists. Characters are often trying to hide and escape distressing incidents from their past. Where better to hide than out in the open? Red Hill, Mystery Road and Goldstone examine ancestral trauma - both Indigenous and settler. Their narratives challenge official versions of events that cover over and forget historic massacres (or freeze them in dusty time as 'historic displays' for tourists that seemingly never come). Noir characters are forever escaping traumatic incidents from their past. It is by destroying that 'historic display' that Conway and Cooper sow the ground for a different future. It is only in confronting the past, their ancestral trauma that they can they hope for redemption, even if it is at the end of a shotgun.

Outback Noir films are preoccupied with characters lost in a landscape that is at once epic and brutally sublime and scarred by colonial violence, the vibrations of mining and business corruption. Yet the landscape in these films offers a form of healing to the wounds of the ancestors by crafting a kind of investigative communal ceremony that exposes the corruption and softens the light on these sun-blasted people. It is through the police detective's work on the past, performed in collaboration between Indigenous and white people that offers a glimmer of hope against the noir fatalism.

\section{Conclusion}

As noted earlier, Suzette Wearne argued that, "Our collective repressed is haunted by the ghosts of our indigenous past" (Power 2015). Nowhere is this more clearly evident than in 'Waltzing Matilda' as the template for concealing the past and keeping the ghosts hidden in plain sight. Like the 'jolly' swagman, Jimmy Conway is not over-and-done-with, he has come alive in this Outback Noir. Leading film scholar James Naremore makes an important observation on the issue of time in this field, "most contemporary writing and filmmaking associated with noir provokes a mourning and melancholy for the past, made all the more poignant because the objects being mourned are still with us" (1998: 4). Jimmy Conway may be gone, but his ghost remains. It is still with us. It is still tangible. Weird melancholy indeed.

The community of Red Hill nestled in the bucolic hills beyond the dark and menacing streets of Melbourne is riddled with moral ambiguity, criminality and social perversion under the thin veneer of an upright rural community with its own modest historical tableaux that captures the 'history' of the Aboriginal inhabitants. As Ben Goldsmith notes, "the townspeople justify to their actions [raping Conway's wife and framing him for her murder] to themselves as being what they see as the best interest of their town; they are motivated by the desire to ensure its survival and future prosperity. That is, they are motivated by a sense of community, albeit one which deliberately and violently excludes Indigenous Australians" (2015: 220). Red Hill, like many Outback Noir films, focuses on the moral rottenness of small towns with their sheen of 
decency concealing repressed, dark secrets. In the context where old certainties have disappeared, there is a desperate attempt by figures of authority to hold on to their power base at any price. In Red Hill as in Mystery Road and Goldstone the status quo is upset by the intrusion of an outsider, a cop forced to unravel the source of corruption for the community to survive by cleansing itself of its ghosts. What unites these disparate Outback Noir films is not just the aesthetics, the big brutal landscapes, the production processes, the modest budgets, the style and mood, but the prevailing themes of the concealment of old, criminal secrets that bind a community together in past that is full of ghosts and this brings with it a pervading sense of social hopelessness. It is only in overturning the past and reversing polarities that the community have any chance of survival. It is not surprising just how many of these films feature morbid tales of old cops gone rogue. From Wake in Fright with its top copper precipitating the naïve school-teacher's downfall with an introduction to the illegal gambling dens to the crooked policemen of The Cars That Ate Paris, Swerve, Cactus, The Proposition, Sweet Country, Mystery Road and Goldstone - the rogue cop as the ambivalent and twisted source of authority is a prevailing theme. In the Outback Noir the bad cop is narratively tamed and overthrown by the protagonists often in cross-cultural collaboration. In Red Hill, the initially monstrous Jimmy Conway becomes the town's spiritual saviour by cleansing the community of people who went against the moral code. Red Hill is an interrogation of postColonial trauma through and shared retribution between Conway and Cooper that leads to the disappearance of binary certainties of good and evil. Whether examining criminal actions against Indigenous people or uncovering dark secrets from the past - all the Outback Noir films are committed to an investigation of repressed histories of violence and crime that are connected to the law and the land. Outsiders or liminal characters, caught between two worlds, are often the only possible saviours of the community with the denouements cautiously optimistic. The ghost hiding at the basis of many Outback Noir films begs the question of complicity or collaboration - working together... "Who'll come a-waltzing Matilda with me?" As viewer's we participate in a shared, cross-cultural investigation.

\section{Bibliography}

Buckmaster, Luke (2010) 'Interview with Patrick Hughes, writer/director of Red Hill', Crickey, 25 November [https://blogs.crikey.com.au/cinetology/2010/11/25/interview-with-patrickhughes-writerdirector-of-red-hill/]

Catsoulis, Jeannette (2010) 'Western meets horror', The New York Times, 4 November, 2010. [https://www.nytimes.com/2010/11/05/movies/05red.html]

Cockrell, Eddie (2013) 'Sun-drenched film noir', The Australian, 17 August, 2013 http://www.theaustralian.com.au/arts/review/sun-drenched-film-noir/story-fn9n8gph1226698413712

Fitzgerald, Ross (2010) 'Waltzing Matilda an old cold case', ABC 12 February 2010 [https://www.abc.net.au/news/2010-02-12/waltzing-matilda-an-old-cold-case/329506] 
Coolabah, Nr 29, 2021, ISSN 1988-5946, Observatori: Centre d'Estudis Australians $i$

Transnacionals / Observatory: Australian and Transnational Studies Centre, Universitat de Barcelona

Gelder, Ken 'Australian Colonial Gothic' Oxford Research Encyclopedia of Literature: http://literature.oxfordre.com/view/10.1093/acrefore/9780190201098.001.0001/acrefore9780190201098-e-143

Gibson, Ross (2002) Seven Versions of an Australian Badland, University of Queensland Press: St. Lucia, Queensland.

Goldsmith, Ben (2015) 'Red Hill' in Directory of World Cinema: Australia and New Zealand $2^{\text {nd }}$ Edition, Intellect: Bristol, UK/Chicago, USA p. 220

Gordon, Avery (1997) Ghostly Matters: Haunting and the Sociological Imagination, University of Minnesota Press: Minneapolis, London.

Harvey, Kit (2012) 'Red Hill (Patrick Hughes, 2010) 'Key Moments in Australian Cinema', Sense of Cinema, Issue \#64 http://sensesofcinema.com/2012/key-moments-in-australiancinema-issue-70-march-2014/red-hill-patrick-hughes-2010/ [accessed 2 August 2018]

Hobsbawm, Eric (1972) Bandits. Pelican Revised ed, Weidenfeld \& Nicolson, 2001.

Macaulay, Scott (2010) 'A Talk with Red Hill Director Patrick Hughes', Filmmaker Magazine, 4 November 2010, [https://filmmakermagazine.com/15814-a-talk-with-red-hills-patrickhughes/\#.YBS24ulR02w]

Mancan18 (2018) 'Comments' on Patrick Marlborough's article in The Guardian [https://www.theguardian.com/music/2018/oct/31/waltzing-matilda-is-australias-creepiestballad-let-me-tell-you-why]. 1 November 2018, 9:42am

Marlborough, Patrick (2018) 'Waltzing Matilda is Australia's creepiest ballad. Let me tell you why.' The Guardian, 31 Oct 2018 https://www.theguardian.com/music/2018/oct/31/waltzingmatilda-is-australias-creepiest-ballad-let-me-tell-you-why\#comment-122081045 [Accessed 5 December 2019]

Naremore, James (1998) More than Night: Film Noir in Its Contexts, University of California Press: Berkley and Los Angles.

Power, Liza (2015) 'Weird melancholy: exhibition probes fear at the heart of the Australian Landscape', The Sydney Morning Herald, April 3. [https://www.smh.com.au/entertainment/weird-melancholy-exhibition-probes-fear-at-theheart-of-the-australian-landscape-20150328-1m9uk2.html] Accessed 13 February 2020.

Silver, Alain and Ursini, James (2004) Film Noir, Taschen: Germany.

Greg Dolgopolov teaches and researches at UNSW in video production, film festivals and film theory and literacy. His research interests include film festivals, short films, film distribution, Australian and post-Soviet cinema and the crime genre. He has written extensively on historical television detective serials, reality game shows and more. His research has been published in Social Semiotics, Senses of Cinema, Metro, Lumina, Real Time and Kinokultura. Greg is a 
Coolabah, $N r$ 29, 2021, ISSN 1988-5946, Observatori: Centre d'Estudis Australians i Transnacionals / Observatory: Australian and Transnational Studies Centre, Universitat de Barcelona

documentary and drama filmmaker. The Really True History of the Ned Kelly Gang (2019) appeared at the Vladivostok International Film Festival. Greg is the artistic director of the Vision Splendid Outback Film Festival (2013 - ), Short+Sweet Film Festival (2017 - ), the Russian Resurrection Film Festival (2008 - ) and the internationally touring Best of Australian Shorts Festival. 